Snežana Božanić

Univerzitet u Novom Sadu

Filozofski fakultet

Odsek za istoriju

sbozanic5@gmail.com
Originalan naučni rad

primljeno: 22. mart 2013

prihvaćeno: 1. oktobar 2013

\title{
SRPSKI VELIKAŠI U POLITIČKIM I VOJNIM PREVIRANJIMA OKO IZBORA VLADISLAVA II ZA KRALJA UGARSKE*
}

Sažetak: Od sredine šezdesetih godina XV veka, na teritoriju južne Ugarske počeli su prelaziti brojni srpski velikaši. Dobivši titule i posede, despot Vuk Grgurević, braća Jakšić, Miloš Belmužević a potom Đorđe i Jovan Branković verno su služili ugarskog kralja Matiju. Međutim, nakon njegove smrti, 6. aprila 1490. godine, postavilo se pitanje izbora novog kralja. Ugarska je bila podeljena na pet frakcija. Poput ostalih ugarskih plemića i Srbi sa prostora južne Ugarske će u narečenim događajima menjati strane $i$ često se nalaziti u protivničkim taborima. Za vreme bitke kod Šarviza, bili su u trupama maloletnog Ivaniša kao i njegovog suparnika. Sremski Brankovići su najpre pristali uz sina pokojnog kralja, zatim su podržali Maksimilijana i naposletku, u proleće 1491. godine, Vladislava II. U danima posle smrti kralja Matije, velikaš Miloš Belmužević podržao je kralja Vladislava II i ostao mu je veran do kraja života. Pored brojnih izvora i literature, rad se u velikoj meri oslanja na kazivanje Antonija Bonfinija koji o narečenim događajima piše u poslednje tri knjige dela Rerum Ungaricarum Decades, tomus IV.

Ključne reči: Matija Korvin, Vuk Grgurević, Sremski Brankovići, Jakšići, Miloš Belmužević, Vladislav II.

Na Veliki utorak, 6. aprila 1490. godine, upokojio se jedan od najvećih vladara srednjovekovne Ugarske, neumorni ratnik, zaštitnik svekolikog hrišćanstva, mecena i dobrotvor, graditelj, pokrovitelj humanizma i renesanse, kralj Matija Korvin (1458-1490).

Najveći deo života proveo je na ratištima širom srednje i južne Evrope. U njegovoj pratnji neretko su se nalazili srpski velikaši, koji su dali značajan doprinos brojnim pobedama ugarskog vladara. Dakle, za vreme Matije Korvina, na teritoriju južne Ugarske prešli su brojni predvodnici srpskog plemstva.

Pre svih, treba istaći unuka despota Đurđa Brankovića i vanbračnog sina slepog Grgura (potonji monah German) Vuka Grgurevića, prvog despota Srba u južnoj Ugarskoj. Da je on sredinom šezdesetih godina XV veka bio jedan od najbližih kraljevih saradnika,

\footnotetext{
* Tekst je nastao kao fazni rezultat rada na projektu BVojvođanski prostor u kontekstu evropske istorije (broj 177002) Ministarstva prosvete, nauke i tehnološkog razvoja Republike Srbije i projekta Srednjovekovna naselja na tlu Vojvodine. Istorijski procesi i događaji (br. 114-451-2216/2011), koji finansira Pokrajinski sekretarijat za nauku Vlade Autonomne Pokrajine Vojvodine.
} 
znao je i turski sultan Mehmed II Osvajač. ${ }^{1}$ Kao „prekaljeni ratnik“ posebno se istako tokom rata protiv Đorđa Pođebrada (Юрий Подебрад, 1458-1471). Posle pomenutog sukoba, nizali su se Vukovi ratni uspesi na strani kralja Matije. Istakao se prilikom osvajanja Šapca 15. II 1476. godine. ${ }^{2}$ Učestvovao je, između ostalog, u bitkama kod Požežene, Bečeja, na Uni i Hlebnom polju. ${ }^{3}$ Zbog brojnih zasluga, Matija je despotu Vuku darovao Belu Stenu u Slavoniji (Križevačka županija) a potom i Tetuševinu. Držao je $\mathrm{Irig}^{4}$, Berkasovo i Kupinik. Kasnije, 1482. godine dodelio mu je kaštele i tvrđave Komagojno i Gradisu. U njegovom posedu bila je i Kostajnica na Uni. ${ }^{5}$ Prvi srpski despot, koji je dobio titulu od ugarskog vladara i istakao se u ratovima protiv Turaka, Čeha, Poljaka i Nemaca, umro je 16. aprila 1485. godine. ${ }^{6}$ Neumorni ratnik, despot Vuk, hrabro, požrtvovano i odano, sve do svoje smrti služio je ugarskog kralja.

Stefan i Dmitar Jakšić, potomci Jakše Breščića, obreli su se u drugoj polovini 1464. u Ugarskoj. ${ }^{8}$ Od kralja Matije dobili su vlastelinstvo u Čanadskoj županiji i grad Nađlak. ${ }^{9}$ Kao predvodnik barjaktara, tokom rata Ugarske protiv Poljaka (1473-1474),

\footnotetext{
${ }^{1}$ Antonijus Bonfinis, Rerum Ungaricarum Decades, tomus IV - pars II (ediderunt Margarita Kulcsar et Petrus Kulcsar), Budapest 1976, 9; Vilmos Fraknói, Mátyás király levelei I, Budapest 1893, 78; Сима Ћирковић, O деспоту Вуку Гргуревићу, ЗМСЛУ 6, 1970, 286-287; Dušanka Dinić-Knežević, Sremski Brankovići, Istraživanja $4,1975,8$.

${ }^{2}$ Lajos Thallóczy, Antal Áldásy, Magyarország melléktartományainak oklevéltára (1198-1526), Budapest 1907, № CCCLXVIII, 265; Љубомир Стојановић, Стари српски родослови и летописи, Београд, Ср. Карловци 1927, 250, № 771; Сима Ћирковић, Шабац у средњем веку, Шабац у прошлости I, Шабац 1970, 85-114.

${ }^{3} \mathrm{O}$ bici kod Požežene opširnije pogledati: Lajos Thallóczy, Antal Áldásy, Magyarország melléktartományainak oklevéltára II, A. Magyarország és Szerbia közti összeköttetések oklevéltára, Monumenta Hungariae historica, Diplomataria XXXIII, Budapest 1907, 269-270; L.Thallóczy, A. Áldásy, Magyarország melléktartományainak oklevéltára (1198-1526), № CCCLXXI, 469-479; Алекса Ивић, Из историје Срба у Угарској, Од пада Смедерева до смрти деспота Вука (1459-1485), ЛМС 260, св. VIII, 1909, 25; Алекса Ивић, Историја Срба у Војводини, од најстаријих времена до оснивања Потиско-поморишке границе (1703), Нови Сад 1929 (репринт 1996), 21; D. Dinić-Knežević, Sremski Brankovići, 12; Za boj kod Bečeja, opširnije pogledati: Војводина I, од најстаријих времена до велике сеобе, Историјско друштво у Новом Саду, Нови Сад 1939, 168 (Д. Поповић); Константин Јиречек, Историја Срба I, Београд 1952, 412; ИСН II, Београд 1982, 387 (С. Ћирковић); Za bitku na Uni pogledati: Мавро Орбин, Краљевство Словена (прев. З. Шундица, предговори: М. Пантић, Р. Самарџић, Ф. Баришић; коментари и извори С. Ћирковић), Београд 2006², 130; Nicolae Jorga, Notes et extraits pour servir a l'histoire des croisades au XV siècle V, Paris 1899-1916, 136-139; Bitka na Hlebnom polju: Vilmos Fraknói, A Hunyadiak és a Jagellók kora (1440/1526), Budapest 1896, 282.

${ }^{4}$ Љубомир Стојановић, Старе српске повеље и писма I-2, Београд - Ср.Карловци 1934, 487, № 1.

${ }^{5}$ Za pomenuta darivanja detaljnije pogledati: V. Fraknói, Mátyás király levelei I, 78; Matija Mesić, Pleme Berislavića, Rad JAZU 8, 1869, 53-63; Иларион Руварац, Прилошци, в) Feyezkö=Сланкамен?, Зборник Илариона Руварца I, 299-302 (= Стражилово IV (1888), 568-571); Matija Mesić, Građa mojih razprava u „Radu“, Starine JAZU 5, 1873, 120-122.

${ }^{6}$ Љ. Стојановић, Стари српски родослови и летописи, 254, № 792, а, б, в, г.

${ }^{7}$ Jelka Ređep piše o Vuku Grgureviću i poredi Hronike grofa Đorđa Brankovića sa odgovarajućim mestima iz dela Bonfinija i Orbina, Јелка Ређеп, Гроф Борђе Бранковић и усмено предање, Нови Сад 1991, 203-225.

${ }^{8}$ Сима Ћирковић, Rasciani regales Владислава I Јагелония, ЗМСИ 1, 1970, 79-82; СБР IV, Нови Сад 2009, 228 (С. Ћирковић).

${ }^{9}$ Samu Borovszky, A nagylaki uradalom története, Értekezések a történeti tudományok körébol 19, 1900, 519564; Јован Радонић, Прилози за историју браће Јакиића, Споменик СКА 59, Београд 1923, 61-76.
} 
naročito se istakao Dmitar Jakšič. ${ }^{10}$ Naredne godine, hrabro se držao prilikom osvajanja Nađmihalja i Humenje (Homona). ${ }^{11}$ Braća Jakšić su učestvovali u bitkama kod Požežene i na Hlebnom polju, te u pohodu na Srbiju 1480-1481. godine. Do pogoršanja ugarskoturskih odnosa došlo je u jesen 1486, kada je kod Smedereva ubijen Dmitar Jakšić. ${ }^{12}$ To najbolje svedoči o tome koliko je kralj poštovao i uvažao ovog srpskog predvodnika.

Čuveni srpski velikaš, plemić i vojvoda, Miloš Belmužević, početkom osamdesetih godina XV veka prešao je u južnu Ugarsku. ${ }^{13}$ Zbog ,verne službe“ dobio je plemićki naslov „egregius“. Naročito se istakao tokom ratovanja u Šleskoj. ${ }^{14}$

Prvi despot Srba u južnoj Ugarskoj Vuk Grgurević u braku sa Barbarom Frankopan, ćerkom hrvatskog velikaša Sigismunda Frankopana, nije imao dece. Ugarski kralj je odlučio da za novog predvodnika Srba imenuje Đorđa Brankovića, sina slepog Stefana i Angeline, ćerke Arijanita Komnina i Marije Musaki. ${ }^{15}$ Braća Đorđe i Jovan, zajedno sa sestrom Marijom, detinjstvo i ranu mladost proveli su u Furlaniji, živeći u skromnim materijalnim uslovima. Nakon očeve smrti, 9. oktobra 1476. godine, nastanili su se u Štajerskoj. ${ }^{16}$ Pošto je primio poziv od vladara Ugarske, Đorđe je zajedno sa majkom i bratom preko Beča krenuo za Budim gde je postavljen za despota. ${ }^{17}$ Brankovići su bili uklopljeni u ugarski feudalni poredak, vršili su vojnu službu i zakleli se na vernost kruni Sv. Stefana. ${ }^{18}$ Porodica je mošti oca i supruga, slepog Stefana, položila 15. februra 1486. u crkvu Sv. Luke u Kupiniku. ${ }^{19}$ Držali su deo poseda despota Vuka Grgurevića.

\footnotetext{
${ }^{10}$ U trećoj knjizi četvrte dekade, dela Rerum Ungaricarum Decades, Bonfini nas detaljno izveštava o ovom ratu; А. Ивић, Из историје Срба у Угарској, 23; А. Ивић, Историја Срба у Војводини од најстаријих времена..., 18, nap. 2.

11 Јован Радонић, Гроф Борђе Бранковић и његово време, Београд 1911, 816-820; Војводина I, од најстаријих времена до велике сеобе, Нови Сад 1939, 207-208, nap. 33 (Д. Поповић)

${ }^{12}$ Imre Nagy, Albert Nyáry, Magyar diplomacziai emlékek Mátyás király korából III, Budapest 1875-1878, 376; Љ. Стојановић, Стари српски родослови и летописи, 255, № 798, а, б, в, г.

${ }^{13}$ O Milošu Belmuževiću opširnije pogledati: Ненад Лемајић, Белмужевићи, Истраживања XIII, 1991, 73-80; Ненад Лемајић, О неким нејасним питањима из историје породице Белмужевић, Međunarodni naučni skup Balkan i Panonija kroz istoriju (ur. S. Gavrilović), Filozofski fakultet u Novom Sadu, Odsek za istoriju, Novi Sad 2006, 115-122; Nenad Lemajić, Srpski narodni prvaci, glavari i starešine posle propasti srednjovekovnih država, Novi Sad 1999, 32-33, 76, 153-154; Ненад Лемајић, Српска елита на прелому епоха, С. Митровица - Источно Сарајево 2006, 38, 64-65, 89-90, 181-182, 196-206, 226.

${ }^{14}$ Zbog brojnih zasluga, dobio je Moišu i Poznad u Tamiškoj županiji, Feketić i Fejeređhaz u Bačkoj, Munaru i Geduš Čanadskoj, Kokot u Tamiškoj, i grad Šašvar u Netranjskoj županiji. Držao je Jenovo, Deg, polovinu Šipsova i Male Đarmate. Ненад Лемајић, Српско становништво Баната и Поморишја у XV и XVI веку, Средњовековна насеља на тлу Војводине, историјски догађаји и процеси (ур. Ђ. Харди), Филозофски факултет у Новом Саду, Одсек за историју, Сремска Митровица 2013, 7-8, nap. 6.

${ }^{15}$ Franc Miklosich, Marija kći Angelina i Konstantin Arijanit, Rad JAZU 12, 1870, 1-9; Жumuje decnomuue Ангелине (изд. Д. Руварац), Српски Сион 15, 1905, 552-553; Иларион Руварац, О роду деспотице србске Анђелине и срећи Деспине Марије, Зборник Илариона Руварца I, Београд 1934, 36-40.

${ }^{16}$ Љ. Стојановић, Стари српски родослови и летописи, 251, № 777, а, б; Ђорђе Сп. Радојчић, Хагиолошки прилози о последњим Бранковићима, ГИДНС 12, 1939, 288-289.

17 Снежана Божанић, Политичка и културна делатност деспота Ђорђа Бранковића у Срему, Војвођански простор у контексту европске историје (ур. В. Гавриловић), Филозофски факултет у Новом Саду, Одсек за историју, Нови Сад 2012, 117, nар. 26.

${ }^{18}$ D. Dinić-Knežević, Sremski Brankovići, 5-6; Сима Ћирковић, Поствизантијски деспоти, ЗРВИ ХХХVIII, 1999-2000, 399-400.

19 Љ. Стојановић, Стари српски родослови и летописи, 255, № 795, а, б.
} 
Dobili su Kupinik, Berkasovo ${ }^{20}$, Irig $^{21}$, Jarak (castellum Arky) ${ }^{22}$ i druga mesta u Sremu. Pretpostavlja se da je do 1490. godine despot Đorđe proveo izvesno vreme na ratištu u Austriji. Sasvim je moguće da se 1487. godine nalazio pod Bečkim Novim Mestom. ${ }^{23}$ Određena grupa srpskih velikaša sa vojskom bila je stacionirana u blizini Linca, u vreme smrti kralja Matije. ${ }^{24}$

Srpski despoti i velikaši koji su prešli u južnu Ugarsku dobijali su posede, a zauzvrat su bili dužni da sa određenim brojem vojnika učestvuju u vojnim operacijama na strani kralja Matije. Prilikom osvajanja Nađmihalja i Humenje 1474. godine, Dmitar Jakšić, „zapovednik barjaktara i lake konjice“, predvodio je odred od 500 konjanika. ${ }^{25}$ Kasnije, na Hlebnom polju (13. oktobar 1479. godine), pridružio se Pavlu Kinjižiju sa trupama od oko 900 Srba. ${ }^{26}$ Prilikom rata 1477. između kralja Matije i Fridriha III, trojaku Matijinu vojsku koja je brojala oko 10.000 vojnika, činili su Česi, Ugari i Srbi. Laku vojsku - barjaktare, u narečenom ratu, činili su Srbi. ${ }^{27}$ Despot Đorđe je predvodio odred od 1.000 ratnika i bio je u obavezi da na poziv ugarskog vladara učestvuje u vojnim operacijama. Banderij Miloša Belmuževića je ponekad brojao i više od 1.000 ratnika. Drugi velikaši su predvodili manje odrede od 400 a ponekad 200 ili 100 konjanika. $^{28}$

Kralj Matija je za života pokušao da osigura presto svom vanbračnom sinu Ivanišu. On je „unapred tugovao nad Ivaniševom sudbinom“ jer nije rođen kao legitimni naslednik. ${ }^{29}$ Znao je Matija da će njegov sin jednog dana zbog toga imati velikih problema. Pošto ni nakon deset godina braka sa Betriče kralj Matija nije dobio potomstvo, sve svoje nade u potpunosti je usmerio na Ivaniša. Nameravao je da ga ustoliči za novog kralja, ukoliko u međuvremenu ne bude imao druge dece. Prema Bonfiniju, dečak je ličio na oca, bio je plemenitog izgleda i izuzetno darovit. ${ }^{30}$ Nastojao je da izgradi njegov autoritet i dostojanstvo. Imao je običaj da prilikom prijema stranih delegacija, te u

${ }^{20}$ József Teleki, Hunyadiak kora Magyarországon XII, Pesten 1857, 303-304; Georgius Pray, Annales rerum Hungariae IV, Vindobonae 1767, 185-186; К. Јиречек, Историја Срба I, 354.

${ }^{21}$ Н. Лемајић, Српска елита на прелому епоха, 43, 82 .

${ }^{22}$ Душанка Динић-Кнежевић, Словенски живаљ у урбаним насељима средњовековне јужне Угарске, ЗМСИ 37, 1988, 20.

${ }^{23}$ Prilikom osvajanja Bečkog Novog Mesta, Matija je lično raspoređivao saborce i delio im zaduženja. Svaki odred je imao barjake: „najpre zastave hrišćanske vere, zatim dinastije Korvina, potom nepobedivog ugarskog naroda i, najzad, Češkog kraljevstva, Dalmacije i južnih zemalja“, A. Bonfinis, Rerum Ungaricarum Decades, tomus IV, lib. VIII, 153.

${ }^{24}$ Imre Nagy, Albert Nyáry, Magyar diplomacziai emlékek Mátyás király korából IV, Budapest 1878, 379.

${ }^{25}$ Јован Радонић, Гроф Борђе Бранковић и његово време, 816-820; А. Ивић, Историја Срба у Војводини од најстаријих времена..., 18, 19, nар. 1.

${ }^{26}$ Франц Бабингер, Мехмед Освајач и његово доба, Београд 1968, 326.

${ }^{27}$ V. Fraknói, A Hunyadiak és a Jagellók kora (1440/1526), 265; Vjekoslav Klaić, Povijest Hrvata, od najstarijih vremena do svršetka XIX stoleća IV, 129-130; Петер Рокаи, Золтан Ђере, Тибор Пал, Александар Касаш, Историја Мађара, 165 (П. Рокаи).

28 Лексикон српског средњег века (прир. С. Ћирковић и Р. Михаљчић), Београд 1999, 99-102 (А. Веселиновић).

${ }^{29}$ A. Bonfinis, Rerum Ungaricarum Decades, tomus IV, lib. VII, 139.

${ }^{30}$ Prema Bonfiniju: „Ivaniš nije imao nemiran i unezveren pogled, već spokojan i usredsređen i uopšte je držanjem, pokretima te ukupnom pojavom - ostavljao utisak kraljevskog dostojanstva, a njegova inteligencija i reči bili su sasvim u skladu sa tim. Nije delovao ni najmanje mrzovoljno, setno niti strogo - naprotiv, zračio je vedrinom i širokogrudošću«, Isto, lib. VII, 139. 
zvaničnim razgovorima sa sveštenstvom i državim delegacijama postavi sina kraj svoje desne strane, pri čemu je slušao njegovo mišljenje.

Vremenom je sve veći broj Matijinih saradnika počeo da podržava njegovog vanbračnog sina. Mudri Matija nije odbijao molbe plemstva koje su bile upućenje njegovom sinu, želeći da jednog dana obezbedi njihovu podršku. U Beču je 1486. primio Antonija Bonfinija koji mu je između ostalog poklonio zbirku koja je bila namenjena Ivanišu, kao budućem vladaru. ${ }^{31}$ Početkom 1487 . Matija je radio na tome da ozvaniči veridbu sestre milanskog vojvode, Blanke Sforca, i mladog Ivaniša Korvina. Međutim, preduslov za sklapanje braka bio je da mladić prethodno dobije kraljevsku titulu. Pošto je osećao da mu se bliži kraj života, žurio je otac da ga oženi. Planirao je da dečaku ,zavešta Češko kraljevstvo, prošireno na posede u Šleziji i Lužici““. ${ }^{32}$ Dodatni problem mu je predstavljao ugovor iz Bečkog Novog Mesta i činjenica da nije imao pristanak Fridriha III. $^{33}$

Godine provedene $\mathrm{u}$ neprestanim ratovima ostavile su traga na Matijinom telu. Još 1467. hrabro se boreći protiv ustanika u Moldaviji bio je ozbiljno ranjen ,getskom strelom“ u leđa, nedaleko od kičme. Posledice ranjavanja su izazvale ozbiljne zdravstvene tegobe, koje su trajale četiri godine. ${ }^{34}$ Pred kraj života je bolovao od gihta, a tokom 1489 . njegovo zdravlje je bilo ozbiljno narušeno. ${ }^{35}$ Uveliko bolestan, prema Sremcu, Matija je od verskih i svetovnih poglavara tražio da mu se zakunu, čak pet puta, da će njegov sin biti izabran za vladara. ${ }^{36}$ Međutim, kraljeva smrt je donela haos i pometnju u Ugarsku. Iako je Beatriče obećala da će Ivaniša tretirati kao rođenog sina, vreme i događaji će potvrdi suprotno. Još za života, Matija mu je zaveštao brojna utvrđenja a nakon njegove smrti prema odluci Senata kraljeva riznica, čija je vrednost procenjena na oko 400.000

\footnotetext{
${ }^{31}$ U Recu kod Beča, Antonije Bonfini, rodom iz Askolija Pičena, doneo je ugarskom kralju nekoliko svojih dela: prevode Hermogena i Herodijana sa grčkog na latinski, kratku knjižicu o poreklu loze Korvina koju je posvetio kralju, knjigu o supružničkoj smernosti i odanosti adresiranu na Beatriče, delo o istoriji Askolija (Historia Asculana), te zbirku epigrama namenjenu Ivanišu, Matijinom sinu. A. Bonfinis, Rerum Ungaricarum Decades, tomus IV, lib. VII, 143; Milica Kisić, Antonije Bonfinije o istorijskim prilikama u Ugarskom kraljevstvu 1464. $i$ 1465. godine, Извори о историји и култури Војводине 2, (ур. Д. Микавица), Филозофски факултет у Новом Саду, Одсек за историју, Нови Сад 2010, 15.

${ }^{32}$ A. Bonfinis, Rerum Ungaricarum Decades, tomus IV, lib. VIII, 160.

${ }^{33}$ Posredstvom pape Pija II (Enea Silvio Piccolomini, 1458-1464) i biskupa Velikog Varadina, Ivana Viteza od Sredne (na taj položaj je postavljen 1445), došlo je do sklapanja privremenog mira a uskoro i ugovora u Bečkom Novom Mestu (1462-1463) između Fridriha III i Matije Korvina. Rimsko-nemački car se obavezao da će vratiti krunu Sv. Stefana i grad Šopron (Soprony). Za Ugarsku je tada bilo najvažnije vraćanje krune, kako bi Matija mogao pristupiti legitimnom krunisanju. U tom trenutku, nije se ni najmanje činila sporna odredba po kojoj će ukoliko Matija umre bez muških potomaka presto pripasti caru ili njegovom sinu. V. Fraknói, A Hunyadiak és a Jagellók kora (1440/1526), 201.202; V. Klaić, Povijest Hrvata, od najstarijih vremena do svršetka XIX stoleća IV, 37.

${ }^{34}$ O narečenim događajima detaljno je pisala Milica Kisić, Ustanak u Moldaviji 1467. godine kroz pero Antonija Bonfinija, Војвођански простор у контексту европске историје (ур. В. Гавриловић), Филозофски факултет у Новом Саду, Одсек за историју, Нови Сад 2012, 129-136.

35 Brojna znamenja tokom 1489. i početkom 1490. nagoveštavala su kraljevu smrt, Bonfinis, Rerum Ungaricarum Decades, tomus IV , lib. VIII, 162.

36 Ђурађ Сремац, Посланица о пропасти угарског краљевства (прев. с латинског М. Полгар), Београд 1987, 18-19, poglavlje X.
} 
dukata, preneta je na Ivaniša. Međutim, činjenica da Ivaniševo imenovanje za kralja nije bilo potvrđeno zvaničnim aktima otvoriće brojne probleme.

U dramatičnim trenucima za krunu Sv. Stefana su se otimale četiri, odnosno, kako Bonfini piše, ,„pet različitih struja i svaka je jednako vukla na svoju stranu“. ${ }^{37}$ Kao prvi pretendent na presto javlja se Rimsko-nemačko carstvo, kako zbog ogromnog autoriteta tako i zbog „sporazuma koji je Matija svojevremeno, prilikom vraćanja krune, sa Fridrihom potpisao““ ${ }^{38}$ Naime, rimsko-nemački car Fridrih III Habzburški (1440-1493) i njegov sin Maksimilijan (nemački kralj 1493-1508. i rimsko-nemački car 1508-1519) pozivali su se na ugovore iz 1462. i 1463. godine, na osnovu kojih su polagali pravo na ugarsku krunu, ukoliko kralj Matija ostane bez zakonitog naslednika.

Ozbiljan kandidat bio je češki kralj Vladislav, sin poljskog vladara Kazimira IV Jagelonca (1447-1492). Poznato je da je kralj Matija „,̌etvrte godine od krunisanja“ započeo rat sa jeretičkim češkim kraljem Đorđem Pođebradom. ${ }^{39}$ Pošto se Đorđe Pođebrad upokojio 22. marta 1471. godine, na saboru koji je nakon toga sazvan, za novog kralja izabran je Vladislav. On je prema izlaganju poljske delegacije bio stvoren za „uspostavljanje mira u Češkoj“, jer je mnoge karakterne osobine i vrline nasledio od „od Ladislava, Kazimira, Karla i Žigmunda“, pri čemu mu „kruna po naslednom pravu i pripada““. ${ }^{40}$ Dobar deo plemstva će preći na njegovu stranu, kako bi bile sačuvane tekovine Matijinih osvajanja u Češkoj. ${ }^{41}$

Poljaci su pokušali krunu da pridobiju za princa Jana Olbrahta, drugog sina Kazimira IV i potonjeg kralja Poljske (1492-1501). Inače, majka Jana Olbrahta i Vladislava, odnosno supruga poljskog kralja Kazimira IV, Elizabeta, bila je sestra ugarskog kralja Ladislava V Posmrčeta. Ona je naročito želela da ugarska kruna pripadne mlađem sinu.

Loza Aragona je ozbiljno računala na presto jer je udovica kralja Matije Beatriče bila ćerka napuljskog kralja Feranta (Ferdinanda) Aragonskog (1458-1494).

Jaka struja je podržavala Ivaniša Korvina. Prema Bonfiniju, „najverovatnije“ bi sve prošlo bez sporova da on ,nije bio vanbračno dete“. Podržavali su ga brojni predstavnici svetovnog i crkvenog plemstva, koje je Matija zadužio za života. Znajući da njegovog sina ne čeka sjajna budućnost, Matija je „dečaku zaveštao krunu, riznicu, te mnoga utvrđenja, privolevši značajan broj gradskih prefekata i velikaša da se Ivanišu svečno zakunu na vernost“. ${ }^{42}$ Uprkos „nežnim godinama“ neosporna je bila njegova „sposobnost da dostojno nosi ugarsku krunu“. Njegov najveći problem bilo je problematično poreklo i mladost.

Prema italijanskom humanisti iz Askolija, stavovi i mišljenja ljudi varirali su u zavisnosti od toga gde su živeli: „Ko je obitavao u Dalmaciji i ovostranoj Ugarskoj, uvek je držao stranu Rimsko-nemačkom carstvu kao najbližem susedu. Ko je pak živeo preko

\footnotetext{
${ }^{37}$ A. Bonfinis, Rerum Ungaricarum Decades, tomus IV - lib. IX, 171.

${ }^{38}$ Ibidem.

${ }^{39} \mathrm{O}$ toku rata pogledati: Snežana Božanić, O ratu između Matije Korvina i Đorđa Pođebrada u svetlosti kazivanja Bonfinija, Godišnjak FF u Novom Sadu, 2012, 415-425.

${ }^{40}$ A. Bonfinis, Rerum Ungaricarum Decades, tomus IV - lib. II, 36-37.

${ }^{41}$ П. Рокаи, 3. Ђере, Т. Пал, А. Касаш, Историја Мађара, 175 (П. Рокаи).

${ }^{42}$ A. Bonfinis, Rerum Ungaricarum Decades, tomus IV - lib. IX, 171.
} 
Dunava, pokraj Poljske, zalagao se da novi kralj bude Poljak. Oni što su naseljavali regije u blizini granice sa Češkom, podržavali su, logično, češku struju“ “. ${ }^{43}$ Međutim, najveća većina plemstva je vodila prevashodno računa o sopstvenim a ne državnim interesima. Poput ugarskih i hrvatskih, podelili su se i srpski velikaši.

Nakon sprovoda kralja Matije, postavilo se pitanje izbora novog vladara. Ubrzo je došlo do prvih nesuglasica i unutrašnjih razmirica. Urban, nadbiskup Egra, uz podršku Senata, sazvao je za sredinu maja sabor u Pešti, na obali Dunava. Najpre su, sredinom narečenog meseca, stigli Matijini najverniji ljudi: nadbiskup Urban, potom Đorđe, čanadski biskup, Petar Bohi, Emerikov brat, Franjo Aristo i drugi, vodeći sa sobom 2.500 konjanika. Uskoro im se sa 3.500 konjanika pridružio Stefan Batori iz Erdelja. Stigli su zatim Bertold Elderbah, Ladislav Lošonci, Ladislav Maurici, te brojni zapovednici konjice. Pridružili su im se i vitezovi reda Svetog Đorđa.

Sabor na polju Rakoš zvanično je počeo sa radom 7. juna 1490. godine. ${ }^{44} \mathrm{U}$ jednom trenutku pristalice sina poljskog kralja Kazimira IV, Jana Olbrahta, proglasile su ga za novog prestolonaslednika. Pošto je ovaj čin izazvao opšte nezadovoljstvo, došlo je do pustošenja onostrane Ugarske. Za to vreme, Maksimilijan je sa trupama bio u Noriku.

Najpre su se na Saboru prisutima obratili predstavnici Ivaniša Korvina, zatim Maksimilijana, Jana Olbrahta, kralja Ferantea i na kraju vladara Češke. ${ }^{45}$

Nakon efektnog govora češkog poslanstva većina prisutnih, kao i podmićenih, okrenula se češkom kralju. Matijina udovica nije podržavala pastorka. Protivila se njegovoj ženidbi sa Blankom Sforcom, strahovala je od mladića koji je pokazivao „karakterne crte pravog tiranina“. On je čak oterao ispred dvorca neke članove njene svite poreklom iz Napulja a iz zatvora je oslobodio kaločkog nadbiskupa Petra.

\footnotetext{
${ }^{43}$ Ibidem, 171.

${ }^{44}$ V. Fraknói, A Hunyadiak és a Jagellók kora (1440/1526), 339.

${ }^{45}$ Ibidem, 339-342; Italijanski humanista iz Askolija, u devetoj knjizi četvrte dekade, detaljno izveštava o događajima, tokom maja i juna 1490. godine. Na narečenom Saboru najpre su se oglasile pristalice mladog Ivaniša, ističući da je Matija za života želeo da obezbedi sinu presto. Trebalo je poštovati želju vladara koji je značajno teritorijalno proširio Ugarsku i učinio brojna hrišćanska dobročinstva. Iako je Ivaniš bio vanbračni sin, njegove pristalice su isticale da „u Italiji niko tome ne daje na značaju i koliko su zapravo relevantni isključivo lični kvaliteti, te nečija vladarska sposobnost“. Narednog dana nemačko poslanstvo se pozivalo na više puta pomenuti ugovor između Fridriha III i Matije Korvina, po kojem se ugarski vladar obavezao da će kruna pripasti rimsko-nemačkom caru, ukoliko ne bude imao zakonitih potomaka. Izborom Maksimilijana bio bi ojačan savez protiv Turaka. Na kraju su uputili ozbiljne pretnje, ukoliko se ne bude ispoštovao sklopljeni sporazum. Olbrahtovi poslanici su se pozivali na rodbinske veze i na činjenicu da ima brojnu braću, koji stoje Ugrima na raspolaganju. Četvrtog dana poslanici napuljskog kralja Ferdinanda (Ferante Aragonski) su preporučivali Beatriče, te su predložili da ona vlada ,uz pomoć Senata, od čijeg bi saveta i odluke zavisilo i to da li će se ponovo udati ili ne“. Interesantno je da Bonfini donosi opširan govor čeških izaslanika u korist kralja Vladislava. Istakli su da ne nude mito i obećanja, kao ni da ne prete, već isključivo nude razložne argumente. Njegov predstavnik „,nije ni tiranin, ni vlastoljubiv, ni nezrelo dete, već ličnost čovečna, plemenita, milostiva, jednako dorasla i ratu i miru“. Podsećali su na bliskost i prijateljstvo dve zemlje. Naglašavali su da je Vladilav „sestrić pokojnog istoimenog kralja, te praunuk Žigmunda i Alberta, vladara Ugarske i Češke koji su nakon smrti proglašeni svetiteljima“. Njega krase „Žigmundova uzvišenost, Albertova pobožnost, Ladislavljeva čednost, te hrabrost strica Vladislava, negdašnjeg kralja Poljske i Ugarske“. Po majčinoj liniji, on je bio unuk rimskonemačkog cara Alberta, pradeda mu je bio čuveni Žigmund a čukundeda Karlo. Po njima, „Bog sve vidi i pamti“ i neće dopustiti da Vladislav olako „bude lišen svog naslednog prava“. On je potomak rimsko-nemačkih careva i brojnih ugarskih kraljeva. A. Bonfinis, Rerum Ungaricarum Decades, tomus IV - lib. IX, 172-176.
} 
Pošto se zasedanje Sabora odužilo, najzad su 13. juna stigli pečujski biskup Žigmund Ernušt i vojvoda Lavrencije sa nemalom vojskom. Sa njima su, piše Bonfini, bili „srpski despot, potom jajački ban, vranski prior, te ostali glavari donje Ugarske, Hrvatske i Slavonije sa svojim četama“. ${ }^{46}$ Svi zajedno su po italijanskom humanisti imali 7.000 vojnika. Broj pristiglih vojnika potvrđuje i Vencel Gustav (Wenzel Gusztáv). ${ }^{47}$ Vilmoš Fraknoi (Vilmos Fraknói) takođe piše o velikašima koji su se pojavili narečenog dana. ${ }^{48}$ Oni su podržavali kandidaturu Matijinog sina. Između ostalih, tu su bili knez Lovro Iločki (Újlaky Lörinc), vranski prior Bartol Berislavić, knez Bernardin Frankopan, grof Mihajlo Blagajski. ${ }^{49} \mathrm{Na}$ samom početku trvenja oko krune Sv. Stefana, srpski despot Đorđe Branković je podržavao sina pokojnog kralja koji ga je pozvao u Ugarsku i darivao mu brojne posede.

Velikaši, tačnije 8 biskupa i 25 barona, sklopili su 17. juna sporazum sa Ivanišem za slučaj da on ne bude izabran za novog kralja. Prema tekstu ugovora, u tom slučaju on će biti imenovan za kralja Bosne, hercega Slavonije i bana Dalmacije i Hrvatske. ${ }^{50}$ Mladić se obavezao da će vratiti krunu i određene gradove.

Međutim, zbog loše situacije a po nagovoru pristalica, Ivaniš Korvin je odlučio da napusti budimsku tvrđavu sa brojnim plenom. Ubrzo se proširila vest da je vanbračni sin kralja Matije ispraznio državnu blagajnu, te da se sa svojim pristalicama i brojnom vojskom zaputio ka donjoj Ugarskoj. Đurađ Sremac tvrdi da je „bar dvesta kola“ bilo natovareno srebrom, zlatom i ukrasima kraljevske palate. ${ }^{51}$ Do prvog velikog sukoba između pristalica Ivaniša Korvina sa jedne strane i Vladislava s druge došlo je na polju Čont. To je tzv. Polje kostiju (reč csont na mađarskom jeziku znači ,kost“). ${ }^{52}$ Pre narečene bitke, od Ivaniša se odmetnuo vrhovni kapetan Austrije i Beča Stefan Zapolja, a uz određenu novčanu nadoknadu na stranu češkog kralja prešla je i čuvena crna četa kralja

\footnotetext{
${ }^{46}$ Ibidem, 178.

${ }^{47}$ Wenzel Gusztáv, Szerémi Gyorgy emlekirata Magyarország romlásáról 1484-1543, Pest 1857, 31.

${ }^{48}$ V. Fraknói, A Hunyadiak és a Jagellók kora (1440/1526), 342, „Ugyanis június közepe táján Ujlaki Lőrincz herczeg, Erneszt pécsi püspök, Beriszló szerb depota...“

${ }^{49}$ Prema Matiji Mesiću, Bartol Berislavić se prvi put na položaju vranskog priora pominje 1475. godine, M. Mesić, Građa mojih razprava u „Radu“, 120. Tom prilikom podstakao je Berislaviće od Grabarja da napadnu imanja Joba Gorjanskog u Slavoniji. Lelja Dobronić, Viteški redovi, Zagreb 1984, 150-152; Primera radi, on je 1494. tada mladog a potonjeg vesprimskog biskupa i hrvatskog bana Patra Berislavića preporurio nadbiskupu Bakaču koji ga je imenovao kanonikom kaločke crkve. O Petru Berislaviću pogledati opširnije: Enciklopedija jugoslavenskog leksikografskog zavoda 1, Zagreb 1986, 548; Matija Mesić, Banovanje Petra Berislavića za kralja Ljudevita II, Rad JAZU 3, 1868, 1-64; Matija Mesić, Hrvati nakon bana Berislavića do muhačke bitke, Rad JAZU 18, 1872, 77-163; Eduard Peričić, Vranski priori Ivan od Paližne i Petar Berislavić, Radovi instituta JAZU u Zadru XVIII, 1971, 290-321.

${ }^{50}$ Ferdo Šišić, Rukovet spomenika o hercegu Ivanišu Korvinu i o borbama Hrvata a Turcima (1473-1496), Starine 37, 1934, 291-293; Vilmos Fraknói, II Ulászló királylyá választasa, Századok 1885, 107-108; Bonfini, u devetoj knjizi četvrte dekade piše da je (sa mladim Korvinom postignut dogovor da postane kralj Bosne, Hrvatske i Slavonije, te da zadrži riznicu i sva sela i gradove koje mu je na toj teritoriji otac zaveštao“.

${ }^{51}$ Ђ. Сремац, Посланица о пропасти угарског краљьевства, 22, poglavlje X (XIII).

${ }^{52} \mathrm{Na}$ savremenom mađarskom jeziku reč csont [-ja, -ot, ok] označava kost, a mezö [-je/mezeje, -t, k] polje. Emil Palich, Magyar-szerbhorvát kéziszótár, Budapest 1968, 154, 648; Srpsko-mađarski rečnik (prir. Molnar Čikloš Laslo), Beograd 2007, 63, 113.
} 
Matije. ${ }^{53}$ Stefan Batori i Pavle Kinjiži u pratnji brojne vojske krenuli su u susret trupama koje je predvodio Ivaniš. Uskoro je došlo do otvorene bitke u Tolnanskoj županiji. Pristalice kralja Vladislava sačekale su neprijatelja „na malenoj reci po imenu Šio, čije ime na skitskom jeziku znači voda puna mulja“, dok su Ivaniševi ljudi bili na suprotnoj strani obale, „na planini Čonteg“. ${ }^{54}$ Ratna sreća okrenula je leđa Ivaniševoj vojsci „pošto je naročito mnogo Rašana i Vlaha bilo pomešano s Ugrima“, beleži Sremac. ${ }^{55}$ Žrtava je bilo na obe strane. Na bojnom polju, između ostalih, stradali su Ladislav Mauricije, Matija Kiš i Franjo Dombo (Dembaj). Narečena bitka, na polju Chont-Mezee (ili kod Šarviza Sárviz), odigrala se 4. jula $1490 .{ }^{56}$ Najverovatnije se i despot Đorđe Branković obreo kod Šarviza i uzeo učešća u pomenutom boju. ${ }^{57}$ Korvinove pristalice, koje su tog dana pretrpele štetu od oko 100.000 dukata, sklonile su se u Pečuj i obližnje kaštele. Riznica pokojnog kralja je poharana i upropaštena, u najvećoj meri. Uskoro su se Stefan Batori i Pavle Kinjiži vratili za Budim. Dok su Brankovići bili na strani Matijinog sina u pomenutom boju, prema Sremcu, „mnogo Rašana“ je već tada podržavalo češkog kralja. Dakle, u samom startu, Srbi su bili podeljeni na pristalice mladog Ivaniša s jedne strane i češkog kralja s druge strane.

Na Saboru 15. jula 1490. godine za novog vladara Ugarske izabran je češki kralj Vladislav, pod imenom Vladislav II. On je šesnaest dana kasnije, 31. jula 1490. potvrdio ugovor koji je sklopljen sa Ivanišem sredinom juna. ${ }^{58}$

Svečano krunisanje Vladislava II obavljeno je 18. septembra 1490. u Stonom Beogradu. Uz novog kralja stajao je biskup Egra Urban sa desne i nadbiskup Pečuja Žigmund sa leve strane. Ivaniš je nosio krunu Sv. Stefana a pored njega su išli Stefan Batori i Ivan, vitez Svetog Đorđa, Pavle Kinjiži, Matija Gereb, sin starog palatina Ladislav i Ladislav Lošonci sa barjakom.

Mnogi velikaši se nisu odazvali. Pre svih, treba spomenuti depota Đorđa i njegovog brata Jovana Brankovića. Na svečanosti nisu bili, između ostalih, ni herceg Lovro Iločki, kaločki nadbiskup Petar Varadi, kapet Blaž Mađar (Podmanički), kapetan Jakov Sekelj i mnogi drugi. ${ }^{59} \mathrm{U}$ izveštaju koji se datuje 1. novembra 1490. i adresiran je na napuljski dvor, despot Đorđe se prikazuje kao suparnik (emuli - „suparnici“) i oponent ćerke napuljskog kralja. ${ }^{60} \mathrm{U}$ istom kontekstu spominje se i Lovro Iločki. Možda razlog za ovakav stav izveštača treba tražiti u činjenici da je despot Đorđe odbio da se oženi Izabelom Aragonskom, rođakom ugarske kraljice. ${ }^{61}$ Većina uglednih velikaša uskoro će pristati uz sina Fridriha III, Maksimilijana.

\footnotetext{
${ }^{53}$ V. Klaić, Povijest Hrvata, od najstarijih vremena do svršetka XIX stoleća IV, 202.

${ }^{54}$ A. Bonfini, Rerum Ungaricarum Decades, tomus IV - lib. IX, 182.

${ }^{55}$ Ђ. Сремац, Посланица о пропасти угарског краљевства, 22, poglavlje X (XIII).

${ }^{56}$ V. Fraknói, A Hunyadiak és a Jagellók kora (1440/1526), 343.

${ }^{57}$ Imre Nagy, A. Nyáry, Magyar diplomacziai emlékek Mátyás király korából IV, Budapest 1878, 432.

${ }^{58}$ F. Šišić, Rukovet spomenika, 296-297.

${ }^{59}$ Albert Berzeviczy, Aragóniani Beatrix magyar királyné vonatkozó okiratok, Budapest 1914, 173, № CXXII, stoji: „Non comparse lo Duca Laurentio, ni disposta de Servia, nè lo Episcopo Anisho (?) ecclesie, ni un capitano she se shiama Albano“.

${ }^{60}$ Ibidem, 173, № CXXII: „Et dice che lo Duca Laurentio et lo disposto de Servia se mostrano molto emuli de la $\mathrm{M}^{\text {ta }} \mathrm{Ser}^{\mathrm{ma}}$ Regina vostra figliola“.

${ }^{61}$ Животъ архиепископа Максима (прир. А. Вукомановићъ’, Гласник ДСС ХІ, 1859, 127.
} 
Srpski velikaši će u narečenim događajima menjati strane $\mathrm{i}$ često se nalaziti $\mathrm{u}$ protivničkim taborima.

Jan Olbraht je tokom leta zadao silne probleme bratu, jer je sa vojskom iz Poljske upao u Ugarsku. Prema Bonfiniju, Vladislav je bratu kao delegate poslao sremskog biskupa Stefana i češkog sudiju Svibovskog, kako bi ga ubedili da prestane sa pljačkanjem jer je proglašen za legitimnog kralja Ugarske.

Iako je govor delegacije bio prilično efektan, Jan mu je poručio da će se „boriti do poslednjeg daha“ a pritom je kraj sebe ,imao i nemali broj ugarskih pristalica“, piše Bonfini. Tokom jeseni na meti poljskog kraljevića našao se grad Košice. Tu se istakao Dmitar Jakšić, sin vojvode Dmitra i Jele, na strani kralja Vladislava II. On je pobedio izvesnog Tatarina, koji je prednjačio po junaštvu u taboru poljske vojske. ${ }^{62}$ Mladi Jakšić je dočekan sa oduševljenjem među svojim saborcima. Blaž Podmanički i Stefan Rozgonji su podržavali poljskog kraljevića. Tek u februaru 1491. došlo je do mira između braće, sinova poljskog kralja, pri čemu je Vladislav II ustupio Janu neke oblasti u Šleskoj.

U jeseni 1490. velike ratne uspehe postigao je Maksimilijan koji je krenuo iz Austrije na Ugarsku. Posle smrti kralja Matije, velikaš Miloš Belmužević podržao je kralja Vladislava II i ostao mu je veran do kraja života. On i Valentin Čereb sa jednim odredom vojske su potisnuli trupe Maksimilijana ka Stonom Beogradu. ${ }^{63}$

Najveći deo nekadašnjih pristalica Ivaniša Korvina iz Hrvatske, Slavonije i Ugarske preći će lagano u tabor sina Fridriha III. Već u septembru pridružili su mu se Jakov i Nikola Sekelj a ubrzo i knez Lovro Iločki. Promena političke i vojne situacije uticala je i na braću Branković, koji su 1. novembra priznali Maksimilijana za kralja. ${ }^{64}$ To isto su učinili i Ivan Hlapčić Kišhorvat sa braćom, Ivan Berislavić od Grabarja sa sinom Franjom i rođakom Ivanom Martinovim, vranski prior Bartol Berislavić, Lovro Banić (Banffy) i drugi.

Kada je reč o držanju braće Đorđa i Jovana, ne treba zaboraviti činjenicu da je njihovoj porodici Maksimilajanov otac puno pomogao dok su živeli u Italiji. Angelina Branković je nakon suprugove smrti kao pomoć od cara Fridriha III dobila zamak Vajtersfeld u Štajerskoj. Na venčanju njihove sestre Marije sa markgrofom od Monferata bio je prisutan i rimsko-nemački car. ${ }^{65}$ Maksimilijan je 17. novembra 1490. osvojio Stoni Beograd. U pomenutom periodu, despot Đorđe je učestvovao u paljenu imovine pristalica

\footnotetext{
${ }^{62}$ Opširnije pogledati: N. Isthuanffi, Regni Hungariae historia post obitu glor. Mathiae Corvini regis, 9; Ioannis Georgii Schwandtneri, Scriptores rerum Hungaricarum II, 167; Алекса Ивић, О мегдану Дмитра Јакиића, Српски књижевни гласник 21, Београд 1908, 686-690; А. Ивић, Историја Срба у Војводини од најстаријих времена..., 35-36.

${ }^{63}$ I. G. Schwandtnerii, Scriptores rerum Hungaricarum II, Vindobonae 1746, 170; Nicolaus Isthuanffi, Regni Hungariae historia post obitu glor. Mathiae Corvini regis, Coloniae Agripinae 1685, 10; Н. Лемајић, Белмужевићи, 78; Н. Лемајић, О неким нејасним питањима из историје породице Белмужевић, 120.

${ }^{64}$ L.Thallóczy, A. Áldásy, Magyarország melléktartományainak oklevéltára II, 284, № CCCXCVII: „Brankovics György rácz deszpota, testvére János, Hlapchichi Kishorváthi János István és János, továbbá Graborjai Beriszló János fia, Ferencz és Márton fia, János, Frigyes császár fiát, Miksát, magyar királynak ismerik el. (1. novembar 1490. Nagyszentmikós)“; F. Šišić, Rukovet spomenika, 308-309.

${ }^{65}$ К. Јиречек, Историја Срба I, 408.
} 
kralja Vladislava II. ${ }^{66}$ Usled materijalnih poteškoća, Maksimilijan je bio prinuđen da napusti Stoni Beograd i već krajem 1490. obreo se u Bečkom Novom Mestu.

Da situacija u kasnu jesen 1490. nije bila laka za Vladislava II, svedoči i činjenica da je Ivaniš Korvin (Duca Joan) „per sua securità“ držao tvrđave (forteleza) „,de Possonia et de Camara et Tasta et de B - - et de Vicegrado“. ${ }^{67}$

Početkom 1491. usledila je protivofanziva kralja Vladislava II. Na čelu njegovih trupa nalazili su se Stefan Batori, Pavle Kinjiži i herceg Ivaniš. Najverovatnije tokom proleća 1491. godine Brankovići iz Srema su konačno prešli na stranu Vladislava II. ${ }^{68}$ To isto je učinio biskup Sigismun Ernušt i mnogi drugi. Požunskim mirovnim ugovorom (7. novembar 1491) stavljena je tačka na sukob između nemačkog i ugarskog vladara. Kraljevi su potvrdili ugovor u Budimu, Inzbruku i Lincu, krajem iste i početkom 1492. godine ${ }^{69} \mathrm{Na}$ Saboru, ugarski velikaši izdali su povelju 7. marta 1492. godine, kojom potvrđuju odredbe sporazuma u Požunu. ${ }^{70} \mathrm{U}$ narečenoj ispravi spominje se „Georgius Rascie despotus", te Pavle Kinjiži, Ivaniš Korvin, braća Dojčin i drugi. ${ }^{7}$

Protiv sporazuma, po kojem je kruna trebalo da pripadne Maksimilijanu u slučaju da Vladislav II umre bez muških potomaka, ustao je poljski kraljević. Despot Đorđe i brat mu Jovan sa 600 konjanika, sinovi Dmitra i Stefana Jakšića sa 300, te velikaš Miloš Belmužević sa odredom od 1.000 ratnika borili su se 24 . decembra 1491. godine protiv Jana Olbrahta.

Naposletku, Brankovići, Jakšići i Miloš Belmužević našli su se na istoj strani, nakon više od godinu dana. ${ }^{72}$ Posle rešavanja spora sa Maksimilijanom i bitke kod Košica, kralj Vladislav II se konačno učvrstio na vlasti.

Slična situacija ponoviće se nakon Mohačke bitke. Nakon stradanja kralja Lajoša II (1516-1526), zemlja je bila raspolućena između pristalica Ferdinanda I Habsburškog

\footnotetext{
${ }^{66}$ V. Klaić, Povijest Hrvata, od najstarijih vremena do svršetka XIX stoleća IV, 214.

${ }^{67}$ A. Berzeviczy, Aragóniani Beatrix magyar királyné vonatkozó okiratok, 174, № CXXII; Ivaniš je držao Požun, Komarno, Tatu, Beograd i Višegrad. J. Калић-Мијушковић, Београд у средњем веку, 203.

${ }^{68}$ Nicolaus Isthuanffi, Regni Hungariae historia post obitum gloriosissimi Mathiae Corvini regis XXXIV, II, Köln 1685, 9; L.Thallóczy, A. Áldásy, Magyarország melléktartományainak oklevéltára II, 284-285, № CCCXCVIII; 285-286, № CCCXCIX; 287-288, № CD.

${ }^{69}$ Tekstove ugovora pogledati kod: F. Firnhaber, Beiträge zur Geschichte Ungerns unter der Regierung der Könige Wladislaus II und Ludwig II. 1490-1526, Archiv für Kunde österreichischer Geschichtsquellen, Wien 1849, 117, LXXI, sporazum u Pozunu; Ibidem, 126-128, № LXXVIII, Maksimilijanova potvrda od 20. decembra 1491; Ibidem, 124-126, № LXXVII, Vladislav II ratifikuje tekst u Budimu; Ibidem, 130-131, № LXXXI, car Fridrih III potvrđuje mir 14. januara 1492. godine u Lincu.

${ }^{70}$ V. Fraknói, A Hunyadiak és a Jagellók kora (1440/1526), 354.

${ }^{71}$ Friedrich Firnhaber, Beiträge zur Geschichte Ungarns unter der Regierung der Könige Wladislaus und Ludwig II 1490-1526, 135, № LXXXIV, ime srpskog despota je među prvih deset plemića: „Johannes Coruinus dux Sclauinie Oppauie et Lipthouie etc, comes Stephanus de Bathor, Paulus de Kinys, Laurencius dux de Wylak, Petrus Gereb de Wyngarth, et Nicolaus Banffy de Lyndwa janitorum, Ladislaus Orzag de Gwth agazonum, alter Ladislaus de Lossoncz, Georgius Rascie despotus, Andreas et Georgius de Bathor, Bartholomeus Dragfy de Beltewk cubiculariorum regiorum magister, Emericus de Peren, Johanues similiter de Peren, Wilhelmus Pankircher de Zalonak, Antonius de Palocz, Mathias Pangracz de Dengeler, Stephanus de Rozgon, Nicolaus et Georgius fratres de Kanyssa...etc.“

${ }^{72}$ I. G. Schwandtneri, Scriptores rerum Ungaricarum II, 170, 176-177; N. Isthuanffi, Regni Hungariae historia post obitum gloriosissimi Mathiae Corvini regis XXXIV, 10.
} 
(1527-1564) i Jovana Zapolje (1527-1540). Nastupila je podeljenost i među istaknutim Srbima. Tokom septembra 1526. Radič Božić je primio platu od kraljice Marije. Ubrzo je prešao na stranu Jovana Zapolje i ostao mu veran do smrti. ${ }^{73}$ Despot Stefan Berislavić je u početku podržavao Zapolju kao i mnoge druge istaknute ličnosti. Međutim, na stranu kralja Ferdinanda prešao je u proleće 1527. godine. ${ }^{74}$ Radič Božić je bio nepokolebljiv. Jovan Zapolja ga je, na Duhove, 9. VI 1527. postavio za srpskog despota. Poslednji despot Srba u južnoj Ugarskoj Pavle Bakić, posle početne podrške koju je pružio Zapolji, nakon poraza kod Tokaja (1527) prešao je na stranu Ferdinanda I i ostao mu veran do smrti. ${ }^{75}$

Izvori i literatura:

Berzeviczy, A. Aragoniai Beatrix magyar kiralyné életére vonatkozó okiratok, Budapest 1914.

Božanić, S., O ratu između Matije Korvina i Đorđa Pođebrada u svetlosti kazivanja Bonfinija, Godišnjak FF u Novom Sadu, 2012, 415-425.

Божанић, С., Политичка и културна делатност деспота Ђорђа Бранковића у Срему, Војвођански простор у контексту европске историје (ур. В. Гавриловић), Филозофски факултет у Новом Саду, Одсек за историју, Нови Сад 2012, 115-128.

Божанић, С., Срем у периоду од 1502. до 1526. године, Споменица ИА „Срем” 6, 2007, 72-90.

Bonfinis, A., Rerum Ungaricarum Decades, tomus IV (ediderunt Margarita Kulcsar et Petrus Kulcsar), Budapest 1976.

Borovszky, S., A nagylaki uradalom története, Értekezések a történeti tudományok körébol 19, 1900, 519-564.

Војводина I, од најстаријих времена до велике сеобе, Нови Сад 1939.

Dinić-Knežević, D., Sremski Brankovići, Istraživanja 4, 1975, 5-47.

Динић-Кнежевић, Д., Словенски живаљ у урбаним насељима средњовековне јужне Угарске, ЗМСИ 37, 1988, 7-42.

Dobronić, L., Viteški redovi, Zagreb 1984.

Enciklopedija jugoslavenskog leksikografskog zavoda 1, Zagreb 1986.

Животъ архиепископа Максима (прир. А. Вукомановићъ), Гласник ДСС XI, 1859, 125-129.

Житије деспотице Ангелине (изд. Д. Руварац), Српски Сион 15, 1905, 552-553.

\footnotetext{
${ }^{73}$ Učestvovao je 27. septembra 1527. godine u bici kod Tokaja, na strani Jovana Zapolje, koji je doživeo poraz. Kasnije, 20. marta 1528. odigrao se sukob kod Sine. Iako se nalazio u neposrednoj blizini, nije uzeo aktivno učešće u pomenutom događaju. Nakon bitke kod Sine, a zasigurno 28. jula 1528. godine držao je gradove Lipovo (Lippa) i Šoljmoš (Solymos), u županiji Arad. Teško oboleo i već u godinama, despot Radič Božić se upokojio tokom septembra 1528. godine. Njegovi posedi će potom dospeti u ruke Stefana Balentića. N. Lemajić, Srpski narodni prvaci, glavari i starešine posle propasti srednjovekovnih država, 16, 49, 56, 58-59, 77-79, 82, 133134,155, 160; Н. Лемајић, Српска елита на прелому епоха, 66, 92, 265.

${ }^{74}$ Stefan Berislavić je u početku podržavao Zapolju, ali je u proleće 1527. prešao na stranu kralja Ferdinanda I. Prisustvovao je 5. novembra 1527. njegovom krunisanju. Zbog materijalnih poteškoća i teške situacije, napustio je tvrđave Bač i Feleđhaz. Njegov postupak je izazvao gnev kralja Ferdinanada koji je 22. marta 1529. u Špajeru izdao naredbu Jovanu Hoberdanecu od Zalatnoka da ga zarobi zajedno sa majkom. Krajem avgusta 1529. pošlo mu je za rukom da se na putu za Beč oslobodi zatočeništva. Stupio je u službu turskog sultana Sulejmana I Veličanstvenog, koji mu je ustupio posede u Sremu i Slavoniji. Снежана Божанић, Срем у периоду од 1502. до 1526. године, Споменица ИА „Срем” 6 (2007), 72-90.

${ }^{75}$ Ненад Лемајић, Бакићи породииа последњег српског деспота, Нови Сад 1995.
} 
Ивић, А., Из историје Срба у Угарској, Од пада Смедерева до смрти деспота Вука (14591485), ЛМС 260, св. VIII, 1909, 20-43.

Ивић, А., О мегдану Дмитра Јакшића, Српски књижевни гласник 21, Београд 1908, 686-690.

Ивић, А., Историја Срба у Војводини од најстаријих времена до осниваға ПотискоПоморишке граниие (1703), Нови Сад 1929 (репринт 1996).

Историја српског народа II, Београд 1982.

Isthuanffi, N., Regni Hungariae historia post obitum gloriosissimi Mathiae Corvini regis XXXIV, II, Köln 1685.

Јиречек, К., Историја Срба I-II, Београд 1952.

Jorga, N., Notes et extraits pour servir a l'histoire des croisades au XV siècle V, Paris 1899-1916.

Калић-Мијушковић, Ј., Београд у средњем веку, Београд 1967.

Kisić, M., Antonije Bonfinije o istorijskim prilikama u Ugarskom kraljevstvu 1464. i 1465. godine, Извори о историји и култури Војводине 2 (ур. Д. Микавица), Филозофски факултет у Новом Саду, Одсек за историју, Нови Сад 2010, 15-31.

Kisić, M., Ustanak u Moldaviji 1467. godine kroz pero Antonija Bonfinija, Војвођански простор у контексту европске историје (ур. В. Гавриловић), Филозофски факултет у Новом Саду, Одсек за историју, Нови Сад 2012, 129-136.

Klaić, V., Povijest Hrvata, od najstarijih vremena do svršetka XIX stoleća IV, Zagreb 1973.

Лексикон српског средњег века (прир. С. Ћирковић и Р. Михаљчић), Београд 1999.

Лемајић, Н., Белмужевићи, Истраживања XIII, 1991, 73-80.

Лемајић, Н., Бакићи, породииа последњег српског деспота, Нови Сад 1995.

Лемајић, Н., Срби у Срему и ґихови прваци од краја XV до краја XVI века, Зборник МС за историју 52, 1995, 7-19.

Lemajić, N., Srpski narodni prvaci, glavari i starešine posle propasti srednjovekovnih država, Novi Sad 1999.

Лемајић, Н., О неким нејасним питањима из историје породице Белмужевић, Međunarodni naučni skup Balkan i Panonija kroz istoriju (ur. S. Gavrilović), Filozofski fakultet u Novom Sadu, Odsek za istoriju, Novi Sad 2006, 115-122.

Лемајић, Н., Српска елита на прелому епоха, С. Митровица - Источно Сарајево 2006.

Лемајић, Н., Српско становништво Баната и Поморишја у XV и XVI веку, Средњовековна насеља на тлу Војводине, историјски догађаји и процеси (ур. Ђ. Харди), Филозофски факултет у Новом Саду, Одсек за историју, Сремска Митровица 2013, 5-23.

Mesić, M., Banovanje Petra Berislavića za kralja Ljudevita II, Rad JAZU 3, 1868, 1-64.

Mesić, M., Pleme Berislavića, Rad JAZU 8, 1869, 53-63.

Mesić, M., Hrvati nakon bana Berislavića do muhačke bitke, Rad JAZU 18, 1872, 77-163.

Mesić, M., Građa mojih razprava u „Radu“, Starine JAZU 5, 1873, 109-280.

Miklosich, F., Marija kći Angelina i Konstantin Arijanit, Rad JAZU 12, 1870, 1-9.

Nagy I., Nyáry A., Magyar diplomacziai emlékek Mátyás király korából I-IV, Budapest 1875-1878.

Орбин, М., Краљевство Словена (прев. З. Шундица, предговори: М. Пантић, Р. Самарџић, Ф.

Баришић; коментари и извори С. Ћирковић), Београд $2006^{2}$.

Palich E., Magyar-szerbhorvát kéziszótár, Budapest 1968.

Peričić, E., Vranski priori Ivan od Paližne i Petar Berislavić, Radovi instituta JAZU u Zadru XVIII, 1971, 290-321.

Pray, G., Annales rerum Hungariae IV, Vindobonae 1767.

Радонић, Ј., Гроф Борђе Бранковић и његово време, Београд 1911.

Радонић, Ј., Прилози за историју браће Јакшића, Споменик СКА 59, Београд 1923, 61-76.

Радојчић, Сп. Ђ., Хагиолошки прилози о последњим Бранковићима, Гласник ИД НС 12, 1939 , 
285-312.

Ређеп, Ј., Гроф Ђорђе Бранковић и усмено предање, Нови Сад 1991.

Рокаи, П. - Ђере, 3. - Пал, Т. - Касаш, А., Историја Мађара, Београд 2002.

Руварац, И., Стари Сланкамен, Зборник Илариона Руварца I, Београд 1934, 367-410 (= Стари Сланкамен, Земун 1892).

Руварац, И., Прилошщи, в) Feyezkö=Сланкамен?, Зборник Илариона Руварца I, Београд 1934, 299-302.

Руварац, И., О роду деспотице србске Анђелине и срећи Деспине Марије, Зборник Илариона Руварца I, Београд 1934, 36-40.

Сремац, Ђ., Посланийа о пропасти угарског краљевства (прев. с латинског М. Полгар), Београд 1987.

Српски биографски речник 4, Нови Сад 2009.

Srpsko-mađarski rečnik (prir. Molnar Čikloš Laslo), Beograd 2007.

Станојевић, С., Нешто о Јакиићима, Нова искра 3, 1901, 164-165.

Стојановић, Љ. , Стари српски родослови и летописи, Београд - Ср. Карловци 1927.

Стојановић, Љ., Старе српске повеље и писма I-2, Београд - Ср. Карловци 1934.

Schwandtnerii, G. I., Scriptores rerum Hungaricarum II, Vindobonae 1746.

Teleki, J., Hunyadiak kora Magyarországon XII, Pesten 1857.

Thallóczy L. - Áldásy, A., Magyarország melléktartományainak oklevéltára (1198-1526), Budapest 1907.

Thallóczy L. - Áldásy, A., Magyarország melléktartományainak oklevéltára II, A. Magyarország és Szerbia közti összeköttetések oklevéltára, Monumenta Hungariae historica, Diplomataria XXXIII, Budapest 1907.

Ћирковић, С., О деспоту Вуку Гргуревићу, ЗМСЛУ 6, 1970, 286-287.

Ћирковић, С., Rasciani regales Владислава I Јагелонща, ЗМСИ 1, 1970, 79-82.

Ћирковић, С., Поствизантијски деспоти, ЗРВИ XXXVIII, 1999-2000, 399-400.

Ћирковић, С,. Шабаи у средњем веку, Шабац у прошлости I, Шабац 1970, 85-114.

Firnhaber, F., Beiträge zur Geschichte Ungerns unter der Regierung der Könige Wladislaus II und Ludwig II. 1490-1526, Archiv für Kunde österreichischer Geschichtsquellen, Wien 1849.

Fraknói, V., II Ulászló királylyá választasa, Századok 1885, 107-108.

Fraknói, V., Mátyás király levelei I, Budapest 1893.

Fraknói, V., A Hunyadiak és a Jagellók kora (1440/1526), Budapest 1896.

Fraknói, W., Mathias Corvinus, Köning von Ungarn 1458-1490, Freiburg in Breisgau 1891.

Šišić, F., Rukovet spomenika o hercegu Ivanišu Korvinu i o borbama Hrvata a Turcima (14731496), Starine 37, 1934, 189-344.

Wenzel, G., Szerémi Gyorgy emlekirata Magyarország romlásáról 1484-1543, Pest 1857. 


\title{
SERBIAN NOBLES IN THE POLITICAL AND MILITARY EVENTS SURROUNDING THE ELECTION OF VLADISLAV II AS KING OF HUNGARY
}

\begin{abstract}
Summary
From the mid-1560s throughout Southern Hungary, numerous members of the Serbian feudal nobility began to cross the border and take up residence. Having received titles and lands, figures such as despot Vuk Grgurević, Miloš Belmužević, the brothers Jakšić, and later Đorđe and Jovan Branković all served faithfully under King Matthias Corvinus. After the king's death on 6 April 1490, the question of electing the new ruler arose. Hungary was divided into five factions. As with other Hungarian nobles, the Serbs of Southern Hungary would frequently change sides and find themselves in opposing camps. At the Battle of Sárvíz, Serbs could be found in the troops of both the king's minor son Ivaniš and his opponent. The Branković family of Srem first joined the ranks of the dead king's son, then switched their support to Maximilian, until finally rallying behind Vladislaus II in the spring of 1491. In the days following the death of King Matthias, nobleman Miloš Belmužević supported Vladislaus II and remained a faithful retainer to the end of his life. Among numerous other sources, this work takes as its principal source the account of Antonio Bonfini regarding the events as found in the final three books of his work Rerum Ungaricarum Decades, tomus IV.
\end{abstract}

Keywords: Matthias Corvinus, Vuk Grgurević, the Branković line of Srem, the Jakšić line, Miloš Belmužević, Vladislaus II. 